\title{
A ASSUNÇÃO DA PERDA: MEMÓRIA E IDENTIDADE EM ÁRBOL DE FAMILIA (2010), DE MARIA ROSA LOJO
}

THE ASSUMPTION OF LOSS: MEMORY AND IDENTITY IN ÁRBOL DE FAMILIA (2010), BY MARÍA ROSA LOJO

Maria Josele Bucco Coelho ${ }^{1}$

Resumo: As narrativas de histórias de vida são formadas por um movimento que conjuga recordação e imaginação, lembranças e esquecimentos, memórias negadas e reivindicadas. Partindo desse pressuposto, este artigo busca delinear os apelos e deveres de memória que funcionam como estratégias de constituição identitária no romance Árbol de Familia, de María Rosa Lojo, publicado em 2010. Busca-se entrever, por extensão, como a proliferação de todo tipo de discurso memorial nas produções literárias contemporâneas reflete a necessidade da posse de um passado negado ou marginalizado, revelando um intento de (re)apresentar-se, sob um paradigma e um matiz outro. Palavras-chave: Literatura contemporânea, romance, memória e identidade.

Abstract: The narratives of life stories are formed by movement that combines memory and imagination, remembrance and forgetfulness, denied and claimed memories. Based on this assumption, this article seeks to outline the memory appeals and duties that work as strategies of identity formation in the novel Árbol de Familia, published in 2010. It seeks to discern, by extension, as the proliferation of all kinds of memorial discourse in the contemporary literary production reflects the need for possession of a denied or marginalized past, revealing an attempt to present itself (again) under a distinct paradigm and nuances.

Keywords: Contemporary Literature, Novel, Memory and Identity.

Transmitir uma memória e fazer viver, assim, uma identidade não consiste em apenas legar algo, mas sim uma maneira de estar no mundo. Joël Candau, Memória e Identidade, 2012.

1 Discente do Programa de Pós-Graduação em Letras da UFRGS. Professora da Universidade Federal do Paraná: mjosele@yahoo.com.br. 
No olvidemos el Goofus Bird, pájaro que construye el nido al revés y vuela para atrás, porque no le importa adónde va, sino dónde estuvo. Borges, Manual de zoologia fantástica, 1984.

\section{Introdução}

Em abril de 2013, realizaram-se no âmbito da UFPR, as Jornadas $L i$ terárias Latino-Americanas. O evento comemorativo ao Dia Mundial do Livro que congrega a comunidade acadêmica local e se estende ao entorno urbano, celebrando nas escolas, livrarias, bibliotecas, institutos de língua, a representatividade da literatura produzida em espanhol se converteu, no outono curitibano, em um espaço de discussão sobre a produção literária latino-americana na contemporaneidade. Durante a transcursão do encontro, María Rosa Lojo $^{2}$ fez o lançamento da recente edição do romance Árbol de familia, publicado pela primeira vez em Buenos Aires, em 2010. E, entre uma fala e outra, descortinava-se sua condição de sujeito transcultural, inserido e transpassado, conforme afirma Esteves (2013, p. 71), por "uma zona de fronteira em que se misturavam pelo menos três culturas- argentina, castelhana, galega" -. As recordações de uma infância que exigiram a habilidade de tradução cultural - e que foram compartilhadas naquela ocasião - carregavam em si as nuances de quem recebeu o exílio como uma herança para sublimá-lo por meio da expressão literária:

[...] usted me preguntó sobre la familia y los orígenes, eso ha sido, para mí una clave de la escritura. [...] Y para mí eso fue tanto más importante debido a que yo tenía una tradición en el suelo donde había nacido, una tradición que mis padres no pudieran trasmitirme porque la ignoraban, ellos trasmitieron la propia, la tradición española, en dos vertientes - la castellana y la gallega - que son dos culturas distintas aunque estén dentro de un mismo estado nacional. Y...rescatar esas historias de familia para mí fue muy importante porque definía mi propia persona, quien era yo sobre este mundo y de donde había salido (LOJO, 22/04/2013, informação verbal, grifo do autor ${ }^{3}$ ).

2 Maria Rosa Lojo (1954-), nascida na Argentina, filha de espanhóis, é uma das grandes vozes da literatura contemporânea. Tendo publicado dezenas de livros (poesia, ensaio, conto, romance, crítica literária) e recebido inúmeros prêmios nos últimos anos, destaca-se, em sua produção, a problematização de questões referentes à identidade, história e memória.

3 Entrevista concedida a Dimas Floriani, no programa América latina Viva da TV/UFPR durante o transcurso do Evento Jornadas Literárias Latino-americanas. 28min. Disponível em: $<\underline{w w w}$. youtube.com/watch? $\mathrm{v}=\mathrm{N} 4$ FicX8SitM $>$. 
O resgate das histórias a que ela se refere se materializa no mencionado romance Árbol de familia e, evocar essa lembrança, nesse momento, cumpre um dever de memória fundado no desejo de manter viva a experiência aurática ${ }^{4}$ vivenciada naquela ocasião. Ao mesmo tempo, anuncia, igualmente, o revide do olhar, ou seja, um intento, em forma de reflexão e análise-cartográfica, de sistematizar o que foi despertado pela rememoração da experiência vivida e plasmada, literariamente, pela escritora.

Ao expressar o sentimento de sentir-se estrangeira em sua própria terra, Lojo se filia ao grupo geracional que recebeu o desterro como herança, uma vez que a maioria dos espanhóis republicanos exilados na Argentina entendia que aquele era apenas um momento de passagem, que eles voltariam às suas raízes ancestrais e que, portanto, seus filhos haviam nascido naquela terra 'estranha' apenas por uma fatalidade:

[...] mis padres sentían que estaban solo de paso y que sus hijos habían ahí nacido por esas fatalidades de la historia que expulsan las personas del lugar de donde deberían estar. Eso se mantuvo durante mi infancia y adolescencia...la sensación que yo no estaba donde debería estar, ni era quien debería ser (LOJO, 22/04/2013, informação verbal).

A manutenção dos filhos em uma zona de arraigo a uma cultura originária que estava impossibilitada de lhes pertencer concretamente causou um desconforto identitário e uma sensação de inaptidão frente à nova cultura, mas cristalizou-se, em contrapartida, na escrita de Lojo, em um impulso criativo e na busca por laços de identificação:

La última novela que publiqué - Árbol de familia - no casualmente se llama así, tiene una epígrafe que dice, que es una copla popular: Soy gajo de árbol caído/Que no sé dónde cayó. / ¿Dónde estarán mis raíces?/ ¿De qué árbol soy yo? [...] y bien, todo el libro es esa búsqueda por orígenes (LOJO, 22/04/2013, informação verbal).

Nos versos recitados, destaca-se a confissão do desconsolo frente a uma perda herdada e a busca pelas origens por meio da retomada das memórias

$4 \mathrm{O}$ conceito de aura foi desenvolvido por Walter Benjamin. A experiência aurática é entendida como uma categoria de percepção sensorial que envolve e que se comunica com a pessoa inteira. Não se trata, portanto, de uma qualidade do objeto de arte, mas de uma experiência singular vivenciada pelos indivíduos que gera correspondências entre o passado e o presente, que se revelam como 'datas da rememoração' (JANZ, 2011, p. 17). 
familiares. A analogia proposta na quadra popular não poderia ser mais elucidativa desse processo, pois remete à árvore genealógica, àquela que representa quem somos e de onde viemos. No entanto, paradoxalmente, revela a desterritorialização, a dificuldade de fixar uma territorialidade simbólica. Mais que isso, esse jogo metafórico detém uma aparente opção de 'fazer-se' ou 'apresentar-se' como o galho sem árvore definida, reclamando ou advertindo sobre a dificuldade de afiliar-se às tradicionais representações identitárias nas quais os indivíduos são inseridos. A inquietação que impulsa a escrita de Árbol de familia esquadrinha, portanto, um desejo de fundar uma territorialidade presentificada, apropriando-se das fissuras de um passado recordado para reterritorilizar-se no espaço cultural, político, linguístico por meio da expressão estética literária memorialística.

Nesse processo, percebe-se a memória como uma potência, isto é, como um paradigma de recordação formador/(des)construtor da identidade daqueles que, arrojados em contextos de mobilidade cultural, corroboram a percepção de que a "memória não deve ser compreendida como um recipiente protetor, mas como uma força imanente, como uma energia com fins próprios" (ASSMANN, 2011, p. 34).

Por essa razão, esse estudo não toma o romance Árbol de Familia como o invólucro onde se depositaram, mecanicamente, nas duas partes que o compõe - Terra Pai e Lengua Madre - informações arquivadas sobre uma genealogia familiar. Isso porque, além dessa função armazenadora, busca compreender em que medida o texto corrobora o nexo entre memória e identidade, entendida como uma construção ativa e uma interpretação da própria história mediada discursivamente ${ }^{5}$.

Assim, para além dos postulados freudianos sobre os romances familiares ${ }^{6}$, baseados na ideia de que a fabulação de uma genealogia faz parte do desenvolvimento da autonomia dos indivíduos, esse estudo busca entrin-

5 Cf. DE LAURETIS, Teresa. The Essence of the Triangle or, Taking the Risk of Essentialism Seriously: Feminist Theory in Italy, the U.S., and Britain. Differences: A Journal of Feminist Cultural Studies. Providence: Brown University, 1989, p. 12.

6 No texto Romances familiares, publicado originalmente em 1909, Freud disserta sobre a atividade imaginativa que permeia o processo de desenvolvimento da autonomia das crianças em relação aos pais. Segundo ele, ao deparar-se com a percepção da natureza falível dos pais, as crianças passam a imaginar uma ascendência diferente, normalmente superior à qual estão filiados. Trata-se de uma abordagem centrada no indivíduo que explica o desejo de pertencer a outra ordem familiar. No caso deste estudo, as recordações memoriais familiares - vividas, recordadas e reinventadas - são tomadas como fonte de construção identitária que refletem não apenas a experiência individual, mas se inserem em uma comunidade cultural em que a perda das origens, concretada por processos de migração, tem no processo memorial, uma das mais prósperas fontes de identificação. 
cheirar-se entre o individual e o coletivo, delineando como as memórias transgeracionais reivindicadas constroem identidades e definem vinculações de onde emergem o sentimento de pertença.

A percepção de que Mnemosyne, a 'chave da consciência' é, portanto, uma fonte primordial para o que chamamos identidade - "a memória nos faz, nós fazemos a memória" (CANDAU, 2012, p. 16) - é atravessada ainda pela percepção de que os processos memoriais podem ser associados a um coletivo, a um grupo (Halbwachs, Candau). Por essa razão, nessa perspectiva, esse estudo defende que a busca pela ascendência/genealogia materializada em Árbol de familia revela um marco onde se inscrevem, dentro do mesmo quadro social de rememoração, um dos caminhos traçados em busca por mecanismos de identificação, de reterritorialização, compartilhados por indivíduos inseridos em contextos de mobilidade. Essa prerrogativa é defendida por Candau (2012) e corroborada por Bernd, que afirma ser necessário "remontar ao passado, através dos mecanismos da memória, do esquecimento e também da imaginação [...] para melhor entender o presente e, em consequência, nosso próprio estar no mundo" (2013, p. 17).

\section{Sobre o papel da memória na constituição identitária}

De forma bastante incisiva, Bernd (2013) defende o imperativo das estratégias memoriais na sociedade contemporânea ao assinalar a impossibilidade de trabalhar com a identidade individual ou nacional "sem conhecer a trajetória de seus ancestrais ou os mitos, lendas e narrativas da comunidade em que se está inserido" (2013, p. 25). Da mesma forma, Assmann reflete sobre a ascensão dos estudos referentes à memória cultural traduzidos no fascínio engendrado pelas "diferentes questões e interesses que se cruzam, se estimulam e se condensam, provenientes dos estudos culturais, das ciências culturais e da tecnologia da informação" (2011, p. 20).

Esse crescente mnemopotrismo nas sociedades contemporâneas é fruto do que Candau denomina "crise de presentismo" (2012, p. 10) e é caracterizado pelo enfraquecimento e perda dos referenciais tradicionais de pertencimento e pela constituição de identidades por ele denominadas de 'diluídas', ou seja, híbridas e transculturais. Nesse sentido, as lembranças e recordações funcionam como o material com qual se tecem, continuamente, os construtos identitários. Para Halbwachs, ao se reproduzir sem cessar, o processo memorial - constituído tanto por lembranças como por esquecimentos - permite que se perpetue, "como pelo efeito de uma filiação contínua, o sentimento de nossa identidade" (2006, p. 89).

Organon, Porto Alegre, v. 29, n. 57, p. 43-59, jul/dez. 2014. 
No entanto, essa proposição, acentuada pelos intensos processos de mobilidade cultural sofridos/impostos/vividos hodiernamente, atravessa o tempo. Segundo Asmann (2011, p. 54), esse interesse pela memória como provedora de respostas sobre a própria origem e identidade perpassa o século XIX com a formação dos estados nacionais e se aloca ainda mais anteriormente, no período renascentista, em uma conjuntura em que se privilegiava a história das dinastias e onde, posteriormente, os indivíduos legitimavam sua origem familiar para inserir-se em um ambiente cada vez mais próximo da modernidade.

Seguindo uma trajetória temporal ao revés, na antiguidade clássica, a memória exercia uma função de aprendizagem, onde fama e glória eram buscadas por meio da permanência/perpetuação dos relatos e feitos heroicos transmitidos e guardados pela arte poética. Nesse caso, a mnemotécnica e suas formas de armazenamento eram o centro de discussão e curiosidade científica. Essa perspectiva de estudo foi rompida, apenas, na década de 1960, com o resgate da importância das recordações por Yates, na obra $A$ arte da memória. Desde então, predomina a percepção de que há uma diferença entre armazenar/decorar um fato e recordá-lo, uma vez que este último processo não é deliberado, não pode ser aprendido nem ensinado, mas vivido pessoalmente.

Além disso, seguindo essa esteira temporal, há de se destacar a noção de memória coletiva desenvolvida por Halbwachs na década de 1950, essencial para a ascensão dos estudos memoriais ao demonstrar que as lembranças são compartilhadas por membros de um grupo dentro de um quadro social de rememoração. Segundo ele, as memórias de um indivíduo não podem existir desvinculadas do contexto social em que este se insere. Não se trata, obviamente de negar a existência da memória individual, mas de considerar que esta se manifesta dentro de um conjunto de relações sociais que demarcam o engajamento do indivíduo.

Bernd (2013), nessa mesma perspectiva, ressalta que as experiências mnemônicas individuais assumem um caráter coletivo e social, pois nelas se fazem presentes outras pessoas. As memórias, nesse ínterim, são consideradas como construções sociais, uma vez que é dentro do grupo que se determina o que é memorável, bem como quais lugares de memória ${ }^{7}$

7 A noção de 'lugares de memória' foi proposta por Pierre Nora na década de 1980 e, segundo Bernd (2013) tornou-se um conceito "incontornável no âmbito dos estudos da memória" (p. 38). Trata-se da percepção de que a memória se apresenta em uma dimensão espacial, concreta, isto é, em forma de monumentos, túmulos, edifícios, museus, etc. e em uma dimensão simbólica e funcional (materializada no patrimônio imaterial das sociedades). Nesse contexto, percebese de forma mais nítida a memória como construção social, pois as comunidades culturais decidem o que querem lembrar/esquecer/exaltar/anular.

Organon, Porto Alegre, v. 29, n. 57, p. 43-59, jul/dez. 2014. 
devem (ou não) ser preservados. $\mathrm{O}$ ato de memória passa a ser indissociável de um espaço físico, pois "a grande maioria dos grupos forja suas lembranças em um contexto espacial definido (a casa, o apartamento, a igreja, a escola, o bairro, a cidade) e assim cada grupo representa o espaço a seu modo" (BERND, 2013, p. 32).

Por essa razão, a rememoração é uma força centrípeta carregada de imagens passadas que agem sempre no presente, mas também com forte demanda futura, uma vez que funcionam apoiadas nas relações sociais presentes e na própria imaginação, já que os interstícios, os buracos da memória precisam de alguma forma ser preenchidos, formando uma narrativa possível.

É como se, no processo memorial, os indivíduos inserissem, nas lembranças, o futuro desse passado, ordenando-o de acordo com os pressupostos presentes para conferir-lhes sentido. A lembrança é, portanto, "algo distinto do acontecimento passado: é uma imagem, mas que age sobre o acontecimento, não integrando a duração e acrescentando o futuro do passado" (CANDAU, 2012, p. 67). Assmann, igualmente, corrobora essa percepção ao defender que a memória funciona como uma espécie de "ponte entre passado, presente e futuro" (2011, p. 146). Estando vinculada a um portador - grupo, instituição e indivíduo - que sempre procede de modo seletivo, ou seja, na já descrita relação contínua entre recordar/esquecer a memória é responsável pelo estabelecimento de perfis identitários e normas de ação (cf. ASSMANN, 2011, p. 146). Além disso, esse jogo memorial estruturado nas lembranças e esquecimentos possibilita ao indivíduo apropriar-se de sua história pessoal, constituindo uma 'narrativa de identidade'.

Nesse sentido, a relação entre memória e identidade é, desde sempre, uma prática irrevogável. As narrativas que compõe as histórias de vida são formadas por um movimento que conjuga recordação e imaginação, lembranças e esquecimentos, memórias negadas e reivindicadas. Os apelos e deveres de memória, nesse sentido, funcionam como estratégias identitárias que se advogam de modo a garantir filiações ou negar vínculos.

Esse processo é, de certa forma, deliberado e consciente. Os indivíduos não podem controlar as evocações e recordações memoriais, mas são capazes de decidir sobre quando ou como expô-las ou apresentá-las. Tratase, portanto, de uma estratégia de construção identitária que proporciona a materialização de uma narrativa de identidade, discursivamente. Nela, as recordações memoriais são manipuladas ou conjugadas fundando, aos moldes de uma autoficção, a filiação e origem que se deseja exaltar. Para Candau (2009), a "parte da lembrança que é verbalizada (a evocação) não é a totalidade da lembrança. $\mathrm{O}$ que não é expresso nas lembranças 
manifestadas possui assim uma significação social, pois se trata de uma fonte colocada em reserva para futuras representações sociais" (2009, p. 49).

Nesse sentido, a proliferação de todo tipo de discurso memorial nas produções literárias contemporâneas reflete a busca pela posse de um passado negado, subalternizado ou marginalizado, pelo intento de (re) apresentar-se, sob um paradigma e um matiz outro. As narrativas de testemunho, os romances memoriais, autobiográficos, familiares, as sagas e demais textos fundados no ato de rememoração empoderam os grupos que ficaram à margem da hegemonia histórica e social, criando um lugar de enunciação desconstrutor onde se reitera a força discursiva das narrativas, relativizando os processos históricos tradicionais e abrindo passo para novas perspectivas em relação ao passado ao qual se deseja filiar.

No que se refere ao romance Árbol de família (2010), pode-se considerá-lo como uma performance memorial, em que a perda do lugar de origem - ocasionada pelo exílio familiar - transforma aos 'filhos exilados' em seres destituídos de quadros de referência identitários concretos, obrigando-os a traçar, tal qual o Goofus $\mathrm{Bird}^{8}$, um voo ao contrário, onde retomar o passado significa poder viver o presente e construir possibilidades de futuro.

\section{Sobre as estratégias memorias em Árbol de família - a questão da nomeação}

Segundo Candau, "o nome próprio, e mais genericamente toda a nominação do indivíduo ou de um conjunto de indivíduos, é uma forma de controle social da alteridade ontológica do sujeito ou da alteridade representada de um grupo" (2012, p. 67). Essa proposição ganha força no romance Árbol de Familia ${ }^{9}$, na medida em que, as duas grandes partes que o compõe - Terra pai e Lengua Madre - são antecedidas por uma espécie de introdução onde a narradora se apresenta, ao mesmo tempo em que apresenta aqueles que fazem parte de sua árvore familiar.

Sem nomear-se diretamente a si própria, isto é, sem dizer seu nome, a voz em primeira pessoa se define por meio de múltiplas afiliações - "soy la nieta, soy la sobrinha, soy la hija, soy la bisnieta" (AF, 2010 p. 11- 13) - todas funções sociais por ela desempenhadas. Curiosamente, dos onze parágrafos que marcam essa introdução, apenas um se exime de ser cons-

8 Referência ao Goofus Bird - na Zoologia fantástica, de Borges, é um pássaro que constrói o ninho ao contrário e voa para trás.In BORGES, Jorge Luis; GUERRERO, Margarita. Manual de zoología fantástica. México: Fondo de Cultura Económica, 1984.

9 Para fins de citação, nesse artigo se usará a sigla AF para referir-se ao romance Árbol de Familia. 
truído a partir do uso do verbo 'ser'. É apenas por último que a narradora anuncia que vem "de esas, de esos, como quien viene de tantos lugares que ha perdido la memoria de ellos" (AF, 2010, p. 13). Nesse caso, a forma verbal - venir/vir - revela-se como um artefato textual que rompe com a condição (expressa pelo uso do verbo ser) e arroja a narradora a um estado de trânsito e mobilidade.

Esse desalento em relação à perda de um lugar de origem (vinculada à perda memorial de seus próprios antepassados) será, paulatinamente, revogado por meio da evocação das recordações familiares. A narradora ainda não é capaz de dizer quem é, apenas se refere aos lugares sociais a ela destinados. As memórias de seus antepassados, perdidas, serão a fonte dessa narrativa de identidade, recuperada em cada episódio evocado, delineando a saga familiar à qual ela deseja atrelar-se. Por essa razão, é preciso ressaltar que não se trata, unicamente, de salvaguardar a memória dos ancestrais, mas de constituir/garantir/proteger a sua própria.

Nesse processo de constituição identitária, marcado pela impossibilidade de nomear-se de forma concreta e imediata, a narradora enleia seu interlocutor, fazendo-o participar, no presente da leitura, dessa construção. A partir do próprio processo de rememoração, compartilhado com esse leitor atento é que se tecerão, conjuntamente, os fios dessa identidade fragmentada, apresentada a partir de pequenos rasgos, de pequenos vestígios:

Habría otra Rosa de su sangre que el mar separaría sin remedio de las costas gallegas. Otra que viviría sin verlo, una desconocida, hija de sus padres, pero sobretodo, del éxodo, que llevaría puesto su nombre de bautizo como quien porta una joya de familia, o mejor aún, un amuleto contra el olvido. (AF, 2010, p. 57).

Rosa, a narradora, finalmente, vai se desvelando para o leitor. Mas de forma controversa e sutil. Ela é a 'Outra', aquela que viveria o êxodo e que teria como bem mais precioso, uma joia de família, seu nome de batismo. Este, fator primeiro de identificação, é agora apresentado como um dever de memória, um talismã e um amuleto que a ajudará a lembrar-se quem é, de onde veio.

Essa evocação carrega em si o passado dela - o pacto com o diabo que um bisavô temendo a morte no mar teve que fazer - o conjuro de que "una mujer de tu sangre, llamada Rosa, vivirá del outro lado del mar y morirás sin verla" (AF, 2010, p. 56) que se materializa no próprio presente da recordação, o futuro previsto pelo diabo, concretado na experiência da narradora que se intitula "la distante, la que nacería en un país llamado Organon, Porto Alegre, v. 29, n. 57, p. 43-59, jul/dez. 2014. 
exílio" (AF, 2010, p. 57).

Segundo, Candau, "apagar o nome de uma pessoa de sua memória é negar sua existência” (2012, p. 68), consequentemente, o processo inverso, ou seja, restituir-lhe um nome é dar-lhe uma possibilidade de existir. Assim, a narradora, que a princípio reconhece seus laços de pertencimento, mas é incapaz de nomear-se, encontrará por meio do jogo memorial, na evocação das histórias de sua família a capacidade de dizer quem é e que lugar ocupa, mesmo que esse lugar esteja carregado pelo estigma da distância e da mobilidade, como uma maldição diabólica.

Ainda seguindo a esteira desse processo de descobrimento do próprio nome e, portanto, do próprio lugar no mundo, vale a pena recordar o espaço em que essa rememoração se dá. O bisavô, desafiando as convenções e em um ímpeto de coragem, resolve que quer atravessar o oceano em uma embarcação por ele mesmo construída. Sem possibilidades de retorno, em meio a uma tempestade e correndo risco de vida, o intrépido Luís Ventoso precisaria da ajuda do próprio diabo para retornar, não sem antes ter que aceitar o ônus de sua salvação: a perda de uma Rosa, uma descendente que ele imaginava ser sua futura filha, para o exílio. Nesse contexto, viver no estrangeiro, longe das terras galegas, é metáfora de praga demoníaca, ou seja, de uma condição pouco desejável que reflete uma condenação, uma pena a ser cumprida pela insensatez de uma travessia alucinada. Sem deter-se nessa alegoria que faz analogia ao passado histórico do povo ibérico, desde uma perspectiva muito mais melancólica que heroica, vão sendo trançados os fios que compõe uma (re)territorialidade simbólica possível de ser habitada.

No entanto, Rosa sabe-se fruto dessa condenação e a aceita. É por meio da assunção dessa perda de um lugar de origem que ela formula e reivindica seus construtos identitários, reiterando o que Candau denomina de "ideologias que prevalecem nas memórias migrantes" (2012, p. 17). Isto quer dizer que, frente à fragmentação ocasionada pelo exílio herdado, Rosa não nega essa situação, antes sim, a reivindica como elemento distintivo que a ajudará a constituir uma identidade social, nas fronteiras com outras alteridades.

Por isso, Rosa se diz nascida "en un país llamado exilio" e buscará, a partir da assunção dessa condição - e na própria codificação de seu nome -, a força para fazer-se sujeito a partir dos laços distintos de identificação: "el ser de las rosas no radica en un núcleo escondido, sino en la alianza de las delicadas envolturas" (AF, 2010, p. 63).

E é assim que buscará nas envolturas memoriais narradas nos relatos 
curtos e desconexos do romance, a reconstituição de sua cobertura de pétalas, aquela que não apenas lhe acoberta, mas, principalmente, lhe dá formato e tessitura, perfume e lugar.

\section{Sobre a metamemória - a questão das recordações reivindicadas}

Sem deter-se a um fio narrativo ou a uma linearidade temporal ou espacial, o romance Árbol de Familia apresenta uma estrutura que, analogicamente, nos remete à forma como as evocações memoriais se nos apresentam. De forma súbita, desencadeada por uma sensibilidade apenas adivinhada pelo leitor, as histórias de família vão perfilando-se seguindo apenas um critério formal - o vínculo paterno ou materno. Sem uma amarração linear, a tessitura memorial vai sendo construída por lapsos temporais e espaciais que precisam ser alinhavados pelo próprio leitor, num jogo em que a construção de sentidos depende da relação que vai se estabelecendo entre as rupturas que se instauram a cada capítulo.

Nesse sentido, a estrutura formal do romance remonta à própria competência de memória que, forjada entre lembrança e esquecimento, vai, aos poucos, delineando um todo difuso, onde a "a estrutura da recordação, que é sempre descontínua, inclui necessariamente intervalos de não presença" (ASSMANN, 2011, p. 166). O ritmo da narrativa, nessa mesma perspectiva, soma a essa estrutura, pois está marcado pelo tom típico das narrativas orais, reproduzindo as nuances das anedotas contadas, normalmente, em âmbito familiar.

Praticamente isentas de diálogos, as recordações vão sendo narradas por uma Rosa que seduz o leitor ao relatar as aventuras familiares vividas e imaginadas em uma gradação mítica e fundacional. Essa estrutura formal memorialística confunde as típicas formas de classificação da produção literária. Para Esteves, esse romance é um híbrido que se encontra em um "curioso entrelugar discursivo, uma zona indecisa onde se embaralham história, memória e ficção" (ESTEVES, 2013, p. 73). Essa dificuldade de encaixar a narrativa dentro de um esquema/gênero formal e totalizador se instaura exatamente pela liberdade que as evocações memoriais tomam no processo de recordação. Os lapsos, os intervalos de não presença, as letras de canções, poemas e quadras rememoradas e as referências históricas articuladas em um esquema narrativo que se assemelha a uma espécie de "crônica familiar" (ESTEVES, 2013, p. 73) são indícios que permitem afir-

mar e considerar Árbol de Família como um romance de recordação, isto é, Organon, Porto Alegre, v. 29, n. 57, p. 43-59, jul/dez. 2014. 
assentado nas nuances que constituem o processo memorial.

Nesse ínterim, o uso de epítetos para designar os personagens transforma-os em verdadeiros heróis dessa saga familiar - Doña Maruxa, la hechizada (AF, 2010, p. 17); El inocente (AF, 2010, p. 57); Antón, el rojo (AF, 2010, p. 97), Don Alfonso, el de la mina (AF, 2010, p.125); Ana, la Bella (AF, 2010, p. 147), etc -. Esse recurso, além de caracterizar os protagonistas de cada capítulo, inscreve a narradora, Rosa, em uma linhagem, onde o "passado é filtrado e colocado em forma pelo crivo da memória" (CANDAU, 2012, p. 65), desvelando, no presente, aquilo que ela é e o que busca ser, forjando-a como membro de uma comunidade cultural que compartilha formas similares de estar no mundo. Essa percepção encontra ressonâncias na afirmação de Esteves, para quem o romance mantém certo parentesco com as "antigas epopeias paradigmáticas, como a Odisseia" ou com "releituras mais recentes dessa epopeia arquetípica, como Cem anos de solidão, de Gabriel García Marquez" (2013, p. 74).

Percebe-se, portanto, que se trata de uma estratégia de identificação poderosa que assegura o sentimento de pertença ao grupo, mas que está atravessada pelos liames da imaginação, responsáveis pela construção e reivindicação de uma imagem de si mesma. Ao moldurar sua ascendência, a narradora a regenera, inscrevendo-a em uma 'retórica da distinção'.

Para Candau (2012, p. 138), essas irrupções mnésicas, típicas da restauração da identidade individual se tornam mais fortes quando as pessoas experimentam o sentimento de distanciamento de suas origens. Nesses casos, a apresentação discursiva da família passa a ser emblema de identidades culturais desaparecidas ou subterrâneas e exigem, muitas vezes, a ab-reação daquilo que é traumático, doloroso ou indesejável, compondo o que ele designa de metamemória:

A metamemória é uma parte da representação que cada indivíduo faz de sua própria memória, o conhecimento que ele tem e, de outra parte, o que ele diz. É uma memória reivindicada, ostensiva. Porque é uma memória reivindicada, a metamemória é uma dimensão essencial da construção da identidade individual ou coletiva. Em sua forma coletiva, é a reivindicação compartilhada de uma memória que se supõe ser compartilhada. Ela é, a esse nível, a substância mesma do discurso patrimonial que é, sempre, um discurso sobre a memória. Ora, essa metamemória tem, como toda linguagem, efeitos sociais poderosos (CANDAU, 2012, p. 23).

No que se refere à Árbol de Familia, além desse passado epopeico, as 
memórias reivindicadas remetem à vinculação de Rosa a um grupo marcado pelo trânsito e mobilidade, mas receptivo e aberto às diferenças. Nesse sentido, destaca-se o convívio da diferença entre os familiares: o pai ateu e a mãe católica fervorosa, o primo Rafaelito que era bígamo, a vida errante do primo Alfredo e sua esposa Candela, cantora de zarzuelas e operetas que buscavam firmar a vida nos Estados Unidos, o estilo naturalista de Don Alfonso e suas práticas nudistas -. Percebe-se que a narradora, ao reclamar para sua linhagem uma postura marcada pela sensibilidade e respeito ao Outro, experimenta/vivencia uma aprendizagem da alteridade que resulta na descrição de uma genealogia multicultural. Nela, a diferença é celebrada por meio da ostentação da dessemelhança e pluralidade que constituem a visão de mundo de seus ascendentes.

Enquanto estratégia de constituição identitária, há de se ressaltar ainda as recordações reivindicadas pela narradora que enfatizam a importância cobrada pelo trabalho. No capítulo ¿La venganza de las hormigas? (AF, 2010, p. 214) em que Rosa narra os desdobramentos da trajetória de Tio Adolfo - um bon vivant que menosprezava a dedicação sistemática da família de Rosa ao trabalho e que terminou, tal qual a cigarra da fábula de Esopo, condenado a um triste fim invernal - está metaforizado um dos valores familiares preconizados pela narradora na trajetória de seus ascendentes: a importância do trabalho, da dedicação, o respeito àquilo que é conquistado pelo esforço.

Essa postura é reiterada ainda em outras recordações na narrativa. Como, por exemplo, a história da avó Julia que, adolescente, precisa enfrentar a rotina do trabalho doméstico na casa de Dona Margarita (exMargot, amante francesa de um homem poderoso): "No porque ella sea fulana vas a dejar tú de andar derecha” (AF, 2010, p. 158).

Aos poucos, Rosa vai escolhendo, minuciosamente, os galhos aos quais deseja conectar-se, esquadrinhando uma árvore genealógica em que a valoração da virtude, do trabalho, da determinação e da aceitação dos reveses da vida vão sendo incorporados a cada episódio narrado. E é por meio desse processo de reinvindicação memorial que ela, igualmente, desenha um conjunto de traços culturais que operam, engenhosamente, em um quadro de relações, reações e interações sociossituacionais de onde emerge seu sentimento de pertença e explicita a visão de mundo à qual ela se atrela (ou busca atrelar-se) ${ }^{10}$.

10 Essa percepção é defendida por Candau, para quem "as identidades não se constroem a partir de um conjunto estável e objetivamente definível de 'traços culturais'- vinculações primordiais - mas são produzidas e se modificam no quadro das relações, reações e interações sociossituacionais - situações contexto, circunstâncias - de onde emergem os sentimentos de 
Destaca-se, nessa perspectiva, a oposição entre as duas partes que compõe o livro - Terra pai e Lengua madre -. Segundo Assmann, há alguns lugares que são dotados de uma 'força de memória', isto é, são locais das gerações, espaços em que os indivíduos podem fixar e manter uma relação duradoura com as histórias da família (2011, p. 320). Ora, no caso de Árbol de Familia, a narradora, Rosa, fixa uma territorialidade para o ramo paterno da família. Essa determinação, expressa no título da primeira parte do romance, se reitera na consecução das rememorações feitas nos catorze relatos que compõe esse segmento, todos vinculados às (des) venturas familiares em solo galego - "Fisterra, Finis terra, Finisterre" (AF, 2010, p. 139) - ou a ele atreladas, que encontram, na imagem de um corredor imaginário, uma possibilidade constante de retorno.

Durante años, hasta hoy, hubo un corredor, un pasillo prodigioso, entre los montes de Barbanza y la vasta llanura que concluye, sin una ondulación, en el rio inmóvil. Mi padre lo cruzó muchas veces, en su larga enfermedad final [...] Allí era inmortal, y tenía diez años o ninguno o tenía la edad de la montaña y de las huellas vivas, sensibles como cicatrices aún frescas, grabadas por los carros que llevan el toxo durante su paso de siglos sobre la piedra (AF, 2010, p. 132).

O corredor, metáfora das recordações memoriais, permite a volta a esse local mítico, primordial e fundacional onde a saga familiar tem início. Segundo Esteves, essa imagem pode ser considerada como uma chave de leitura do romance, pois remete a uma possibilidade de transcender as "espacialidades e temporalidades convencionais, por onde circularam seus personagens" (2013, p. 88).

No entanto, faz-se necessário contrapor esse 'local de geração' ao seu inverso, expresso na segunda parte do romance - Lengua madre -. Nesse segundo segmento, em que são narradas as memórias vinculadas ao lado materno, não existe possibilidade de retorno, não há corredor possível para uma volta porque não há uma terra para onde seja possível voltar.

Ana, a bela, "nunca había tenido tierra como para dejarme la memoria de ella, ni un paisaje que amase recordar. Había vivido siempre en pisos de alquiler, unos mejores que otros, en las calles viejas del Madrid de Galdós" (AF, 2010, p. 147). Ana é uma desterrada. E como seus iguais, amaldiçoados pelo exílio ou pela falta de posses, constituem exemplos de "formas de

pertencimento, de visões de mundo identitárias ou étnicas". (2012, p. 27).

Organon, Porto Alegre, v. 29, n. 57, p. 43-59, jul/dez. 2014. 
vida moderna que não permitem mais determinações fechadas como essas, que vinculam as pessoas à determinada porção de terra" (ASSMANN, 2011, p. 320). Por essa razão, ela não deixa como herança nenhuma terra onde se possa, pelo corredor memorial, voltar a habitar e só poderá ser recordada por meio de objetos de memória

[...] dos sutiles cañamazos, bordados con letras mayúsculas y minúsculas en distintos estilos y formatos, con números del uno al diez y una inscripción que dice 1906 [...] dos pañuelos, uno de encaje, y otro de seda [...] una pechera con cuello para vestido de mujer [...] un chal de seda, largo, con flecos, de la época de charleston, un relicario muy hermoso, [...] un bolsillito de plata [...] varios duros del siglo XIX [...] han quedado libros (AF, 2010, p. 152-153).

São esses os rastros responsáveis pela evocação das memórias familiares maternas. Em um jogo de presença-ausência são eles que garantem a Rosa o sentimento de pertencimento e vinculação a um passado. Sem uma territorialidade para recordar do lado materno, o único espaço mnemônico passível de ser habitado é a própria língua. Por essa razão, nessa segunda parte do romance, o corredor de memória, o entrelugar que permite e torna possível habitar dois mundos simultaneamente, assume, uma dimensão imaterial - a da língua materna. Aquela que, ao ser utilizada, permite o atravessamento de lugares e o estabelecimento de uma origem, de uma linhagem que permite a Rosa, finalmente, involucrar todos os galhos aos quais se filiou.

\section{Considerações finais}

Memória e identidade estão, como afirma Candau, indissoluvelmente ligadas. Mais que uma volta ao passado, o processo memorial se vincula estreitamente aos enlaces presentes, constituindo uma força poderosa de identificação - individual e coletiva.

No romance Árbol de Familia, as memórias de Rosa, a narradora que recebe o exílio como uma herança, assumem um potencial de força criadora e de representação social. Por meio da reivindicação das memórias de família, ela descobre, aos poucos, sua condição de ser fadado ao trânsito de mundos e culturas diferentes. Sem renegar esse legado multicultural, em uma espiral vertiginosa, ela busca constituir seu lugar no mundo, elegendo as vinculações que melhor expressam essa condição. Assim, a pergunta 
que foi motriz para desencadear o processo mnemônico - “¿De qué arbol soy yo?" (AF, 2010, p. 09) - é finalmente respondida.

São múltiplos os galhos e múltiplas as filiações que constituem essa genealogia familiar onde a perda de um lugar de origem é sublimada na constituição de um ser de identidade transculturada. Essa assunção, alegoria das constituições identitárias das Américas, se insere em um panorama de expressão artística mais amplo onde os processos de migração e mobilidade, forjados pelo/no atravessamento de culturas, encontram nos processos mnemônicos uma fissura onde se vislumbra a possibilidade de construção, invenção, imaginação e criação de lugares (ou corredores) de memória e de identidades possíveis.

\section{BIBLIOGRAFIA}

ASSMANN, Aleida. Espaços da recordação - formas e transformações da memória cultural. Trad. Paulo Soethe. Campinas: Editora da Unicamp, 2011. BERND, Zilá. Por uma estética dos vestígios memoriais. Belo Horizonte: Fino Traço, 2013. - Vestígios memoriais: fecundando as literaturas das Américas. Conexão Letras, Porto Alegre, n. 6, p. 9-15, dez. 2011. CANDAU, Joël. Memória e identidade. Trad. Maria Leticia Ferreira. São Paulo: Contexto, 2012.

ESTEVES, Antonio Roberto. Imagens do exílio: os "corredores da memória” de María Rosa Lojo. In: GONZÁLEZ, Elena Palmero; COSER, Stelamaris (orgs). Entre traços e rasuras - Intervenções da memória na escrita das Américas. Rio de Janeiro: 7Letras, 2013. FREUD, Sigmund. Romances familiares. Livro IX - Obras Psicológicas de Sigmund Freud. [online] Disponível em: www.lacan.orgfree.com/freud/ textosf/romancesfamiliares.pdf. Arquivo acessado em 12 de fevereiro de 2014.

GINZBURG, Jaime; SELDMAYER, Sabrina. Walter Benjamin - rastro, aura e história. Belo Horizonte: Editora UFMG, 2012.

GONZÁLEZ, Elena Palmero; COSER, Stelamaris (orgs). Entre traços e rasuras - Intervenções da memória na escrita das Américas. Rio de Janeiro: 7Letras, 2013.

HALBWACHS, Maurice. A memória coletiva. São Paulo: Editora. Centauro, 2006. 
JANS, Peter Rolf. Ausente e presente. In: GINZBURG, Jaime;

SELDMAYER, Sabrina. Walter Benjamin - rastro, aura e história. Belo

Horizonte: Editora UFMG, 2012.

LOJO, María Rosa. Árbol de familia. Buenos Aires: Sudamerica, 2010. . LOJO, María Rosa. Leitura e escrita (entrevista online concedida a Dimas Floriani para a TV UFPR, programa América Latina Viva no dia 22 de abril de 2013). [online] Disponível em: http://www.youtube.com/ watch?v=N4FicX8SitM. Arquivo acessado em 25 de julho de 2013. RICOEUR, Paul. La lectura del tiempo pasado: memoria y olvido. Madrid: Arrecife/Universidad Autónoma de Madrid, 1999.

SARLO, Beatriz. Tiempo pasado: cultura de la memoria y primera persona. Buenos Aires: Siglo XXI Editores Argentina, 2005.

SELIGMAN, Marcio Silva. História, memoria e literatura - o testemunho na era das catástrofes. Campinas: Editora da Unicamp, 2003.

Recebido em: 16/06/2014. Aceito em: 26/07/2014. 